\title{
PENERAPAN METODE CHERNOFF FACES PADA KINERJA DOSEN JURUSAN MATEMATIKA FMIPA UNTAN
}

\author{
Rohani, Shantika Martha, Nurfitri Imro'ah
}

\begin{abstract}
INTISARI
Metode Chernoff Faces adalah suatu teknik visualisasi berupa metode grafik yang merepresentasikan data multivariat dalam bentuk wajah kartun. Metode ini menampilkan data multivariat dalam bentuk wajah manusia dengan posisi mata, hidung, telinga, dan mulut yang menunjukkan nilai dari variabel dengan bentuk, ukuran, peletakkan dan arah yang berbeda. Penelitian ini bertujuan untuk menggambarkan kinerja dosen jurusan Matematika FMIPA UNTAN menggunakan metode Chernoff Faces. Data kinerja dosen diambil dari penyebaran 98 kuisioner dengan 9 variabel kepada mahasiswa jurusan Matematika FMIPA UNTAN. Hasil Penelitian ini menyimpulkan bahwa kinerja dosen jurusan Matematika di FMIPA UNTAN secara keseluruhan sudah baik.
\end{abstract}

Kata Kunci : Chernoff Faces, kinerja dosen, data multivariat

\section{PENDAHULUAN}

Salah satu institusi yang berperan penting dalam mencerdaskan bangsa adalah perguruan tinggi. Kualitas perguruan tinggi sangat dipengaruhi oleh beberapa faktor seperti: mahasiswa, fasilitas sarana pendukung proses belajar mengajar dan tak kalah pentingnya adalah dosen sebagai tenaga pendidik. Proses pembelajaran yang baik tergantung pada kinerja dosen yang baik dan peranan mahasiswa yang termotivasi baik. Kinerja dosen dalam proses pembelajaran sangat menentukan kualitas pembelajaran dan akhirnya dapat berpengaruh terhadap kualitas lulusannya. Informasi indikator kinerja umumnya disajikan dalam bentuk tabel, diagram batang dan pie chart. Karena penyajian data dalam bentuk tabel, diagram batang dan pie chart sudah biasa dilakukan, maka dalam hal ini digunakan metode Chernoff Faces untuk mengilustrasikan data multivariat pada dua dimensi.

Metode Chernoff Faces adalah teknik visualisasi untuk mempresentasikan data dengan banyak variabel dalam bentuk wajah kartun yang dapat ditentukan hingga lebih dari 18 parameter, yang terdiri dari ukuran wajah, kelengkungan mulut, panjang hidung, posisi pupil dan lain-lain[1]. Variabel yang digunakan diambil dari penelitian yang dilakukan oleh mahasiswa FMIPA UNUD terhadap mahasiswa jurusan Matematika FMIPA UNUD. Variabel-variabel tersebut antara lain, keramahan terhadap mahasiswa; memiliki wawasan yang luas; kreatif, dinamis, dan inovatif; bijak dalam menghadapi masalah; bersikap dan berperilaku jujur; cara menyampaikan materi sistematis; teknik menyampaikan materi menarik; bersikap komunikatif; serta berpenampilan rapi dan sopan. Masingmasing variabel mencerminkan bentuk pada wajah[2]. Hasil penelitian ini diharapkan dapat dijadikan sebagai dasar evaluasi kinerja dosen di jurusan Matematika FMIPA UNTAN dalam bidang pengajaran.

\section{UKURAN PEMUSATAN DATA}

Ukuran deskriptif berupa angka atau nilai numerik sering digunakan untuk menjelaskan karakteristik data. Dikenal dua jenis ukuran deskriptif yang umum digunakan, yaitu ukuran pemusatan dan ukuran penyebaran.Ukuran pemusatan digunakan untuk menjelaskan lokasi pusat distribusi dari nilai-nilai pengamatan [3], sedangkan ukuran penyebaran digunakan untuk menunjukkan bagaimana variasi/keragaman nilai-nilai pengamatan tersebut terhadap pusat distribusinya. Salah satu ukuran 
pemusatan yang paling sering digunakan adalah modus. Modus dari suatu set data didefinisikan sebagai nilai pengamatan yang paling sering terjadi (frekuensinya paling tinggi). Ukuran pemusatan data yang kedua adalah median. Median dari suatu set data didefinisikan nilai pengamatan yang terletak ditengah-tengah ketika data diurutkan. Untuk suatu set data yang kecil dengan jumlah datanya ganjil,maka median adalah data yang terletak ditengah urutan; sedangkan jika jumlah datanya genap median dihitung sebagai rata-rata dari dua data yang terletak ditengah urutan. Ukuran pemusatan data terakhir adalah rata-rata. Rata-rata suatu set dapat didefinisikan sebagai jumlah dari semua nilai pengamatan dibagi dengan banyaknya data. Rumus menentukan rata-rata secara umum sebagai berikut :

Keterangan :

$$
\bar{x}=\frac{\sum_{i=1}^{n} x_{i}}{n}
$$

$\bar{x} \quad=$ Rata - rata

$n \quad=$ Banyaknya data

$\sum_{i=1}^{n} x_{i}=$ Notasi jumlah dari $\mathrm{n}$ buah nilai pengamatan

\section{METODE CHERNOFF FACES}

Metode ini pertama kali diperkenalkan oleh Herman Chernoff pada tahun 1973. Tampilan awal Chernoff Faces terdiri dari kepala, mulut, mata, hidung, dan alis mata. Pada tahun 1978, Bruckner menulis program untuk pembuatan Chernoff Faces dengan menambahkan telinga sebagai pelengkapnya. Keenam bagian utama wajah tersebut kemudian diperinci menjadi 20 sifat wajah yang lebih spesifik. Chernoff Faces dapat mengekspresikan kondisi atau keadaan yang sebenarnya pada suatu wilayah atau keadaan seseorang berdasarkan penggambaran raut muka.

Proses merancang Chernoff Faces dimulai dengan memasangkan setiap peubah yang telah ditentukan dengan sebuah sifat wajah. Pemasangan ini dapat dilakukan secara acak maupun melalui perancangan [4]. Selanjutnya, setiap nilai aktual dari data asli maupun hasil transformasinya dipetakan secara linier dari nilai data asal ke nilai data yang telah ditetapkan pada tiap-tiap wajah yang diwakili. Untuk sifat wajah yang tidak terwakili oleh variabel ditetapkan suatu nilai default sehingga bagian wajah tersebut tetap tergambar.

\section{PEMBAHASAN}

Populasi dalam penelitian ini adalah keseluruhan mahasiswa jurusan Matematika FMIPA UNTAN. Sampel yang digunakan dalam penelitian ini adalah 98 responden, yang terdiri dari masingmasing angkatan yaitu 2013,2014, dan 2015 yang menempuh studi di jurusan Matematika FMIPA UNTAN. Dalam penelitian ini, data yang digunakan adalah data primer, yaitu dengan penyebaran kuesioner yang ditujukan untuk mahasiswa jurusan Matematika FMIPA UNTAN. Penyebaran kuisioner dimaksudkan untuk mendapatkan data kuantitatif dan kualitatif dari pendapat mahasiswa setiap angkatan tentang kinerja dosen jurusan Matematika FMIPA UNTAN. Dalam kasus ini, peneliti menetapkan untuk mengambil 98 responden berdasarkan rumus Slovin, yaitu rumus untuk meneliti sebuah sampel dari suatu populasi (taraf signifikansi 5\%), dengan syarat responden sudah pernah mendapat pengajaran dari dosen yang bersangkutan.

Pada penelitian ini menggunakan sembilan indikator untuk menganalisis kinerja dosen. Berikut ini akan dijelaskan mengenai konsep dan definisi variabel-variabel penelitian berdasarkan teori fisiognomi (raut wajah mencerminkan karakter), antara lain :

1. Keramahan terhadap mahasiswa, dipresentasikan dengan panjang mata, lebar mata, jarak antar mata.

2. Memiliki wawasan yang luas, dipresentasikan dengan panjang wajah.

3. Kreatif, dinamis dan inovatif dipresentasikan dengan panjang hidung. 
4. Bijak dalam menghadapi masalah dipresentasikan dengan lebar wajah/bulat wajah.

5. Bersikap dan berprilaku jujur dipresentasikan dengan lebar hidung.

6. Cara penyampaian materi sistematis dipresentasikan dengan panjang alis.

7. Teknik penyampaian materi menarik dipresentasikan dengan kelengkungan alis mata.

8. Bersikap komunikatif dipresentasikan dengan panjang bibir.

9. Berpenampilan rapi dan sopan dipresentasikan dengan kelengkungan bibir.

\section{NILAI PENGUKURAN SKETSA}

Pada pengukuran sketsa Chernoff Faces dibentuk tiga kategori yang diperoleh berdasarkan 11 parameter dari lima bagian wajah manusia yang akan digunakan sebagai pembanding gambaran Chernoff Faces dari masing-masing kinerja dosen Jurusan Matematika FMIPA UNTAN. Berikut tabel nilai pengukuran tiga kategori Chernoff Faces:

Tabel 1 Nilai pengukuran sketsa wajah Chernoff

\begin{tabular}{clccc}
\hline Parameter & $\begin{array}{c}\text { Panjang } \\
\text { (Baik) }\end{array}$ & $\begin{array}{c}\text { Sedang } \\
\text { (Sedang) }\end{array}$ & $\begin{array}{c}\text { Pendek } \\
\text { (kurang) }\end{array}$ \\
\hline \multirow{2}{*}{ Mata } & Panjang mata & 1 & 0,6 & 0,2 \\
& Lebar Mata & 0,6 & 0,4 & 0,2 \\
& Jarak kedua Mata & 0,8 & 0,55 & 0,3 \\
\hline \multirow{2}{*}{ Wajah } & Panjang Wajah & 1 & 0,75 & 0,5 \\
& Lebar wajah & 0,4 & 0,275 & 0,15 \\
\hline \multirow{2}{*}{ Hidung } & Panjang hidung & 0,7 & 0,45 & 0,2 \\
& Lebar hidung & 0,2 & 0,15 & 0,1 \\
\hline \multirow{2}{*}{ Alis } & Panjang alis & 1 & 0,65 & 0,3 \\
& Kelengkungan alis & 1 & 0,5 & 0 \\
\hline \multirow{2}{*}{ Bibir } & Panjang mulut & 1 & 0,65 & 0,3 \\
& Kelengkungan mulut & 4 & 0 & -4 \\
\hline
\end{tabular}

Tabel 1 menyajikan nilai-nilai wajah baik, sedang dan kurang yang menjadi patokan baku dalam membentuk ke 13 wajah dosen jurusan Matematika FMIPA UNTAN. Nilai untuk kategori baik diambil dari nilai maksimum dan nilai untuk kategori kurang diambil dari nilai minimum dari Program STATISTICA 10. Sedangkan nilai untuk kategori sedang diambil dari nilai tengah antara nilai minimum dan nilai maksimum pada program STATISTICA 10. Bagian wajah yang tidak termasuk kedalam variabel penelitian akan diwakilkan oleh nilai default. Adapun interpretasi masing-masing wajah sebagai berikut :

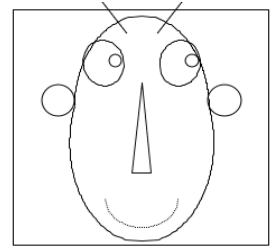

(a)

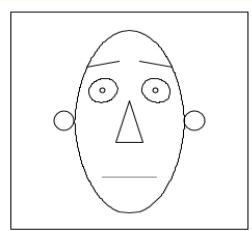

(b)

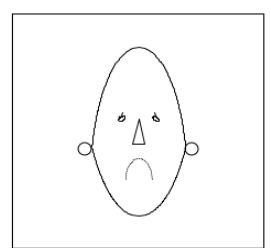

(c)

Gambar 1 Wajah Chernoff Baik (a), Sedang (b), Kurang (c)

Dari Gambar 1, diperoleh masing-masing Chernoff Faces dari tiga kategori yaitu nilai maksimum untuk Chernoff Faces gembira (Gambar 1(a)), nilai tengah untuk Chernoff Faces sedang (Gambar 1(b)), dan nilai minimum untuk Chernoff Faces kurang (Gambar 1(c)). Penjelasan masing-masing 
wajah pada Gambar 1 akan ditampilkan pada Tabel 2 berikut :

Tabel 2 Indikator serta interpretasi wajah Chernoff

\begin{tabular}{|c|c|c|c|c|}
\hline \multirow[t]{2}{*}{ Variabel } & \multirow[t]{2}{*}{ Indikator/ciri wajah } & \multicolumn{3}{|c|}{ Interpretasi wajah Chernoff } \\
\hline & & Baik & Sedang & Kurang \\
\hline $\begin{array}{l}\text { Keramahan } \\
\text { Terhadap } \\
\text { Mahasiswa }\end{array}$ & $\begin{array}{l}\text { Panjang mata } \\
\text { Kemiringan mata } \\
\text { Jarak mata }\end{array}$ & $\begin{array}{l}\text { Mata paling } \\
\text { panjang,mata } \\
\text { paling lebar,dan } \\
\text { jarak mata } \\
\text { paling dekat }\end{array}$ & $\begin{array}{l}\text { Panjang Mata } \\
\text { sedang,lebar } \\
\text { matasedang,dan } \\
\text { jarak mata } \\
\text { sedang }\end{array}$ & $\begin{array}{l}\text { Panjang Mata } \\
\text { pendek, lebar } \\
\text { mata } \\
\text { kecil,dan } \\
\text { jarak mata } \\
\text { jauh }\end{array}$ \\
\hline $\begin{array}{l}\text { Memiliki } \\
\text { Wawasan } \\
\text { Yang luas }\end{array}$ & Panjang wajah & $\begin{array}{l}\text { Panjang wajah } \\
\text { yang paling } \\
\text { panjang }\end{array}$ & $\begin{array}{l}\text { Panjang wajah } \\
\text { yang sedang }\end{array}$ & $\begin{array}{l}\text { Panjang } \\
\text { wajah paling } \\
\text { pendek }\end{array}$ \\
\hline $\begin{array}{l}\text { Kreatif, dinamis } \\
\text { dan inovatif }\end{array}$ & Panjang hidung & $\begin{array}{l}\text { Panjang hidung } \\
\text { yang paling } \\
\text { panjang }\end{array}$ & $\begin{array}{l}\text { Panjang hidung } \\
\text { yang sedang }\end{array}$ & $\begin{array}{l}\text { Panjang } \\
\text { hidung paling } \\
\text { pendek }\end{array}$ \\
\hline $\begin{array}{l}\text { Bijak dalam } \\
\text { menghadapi } \\
\text { masalah }\end{array}$ & Lebar wajah & $\begin{array}{l}\text { Lebar wajah } \\
\text { yang paling } \\
\text { lebar }\end{array}$ & $\begin{array}{l}\text { Lebar wajah } \\
\text { yang sedang }\end{array}$ & $\begin{array}{l}\text { Lebar wajah } \\
\text { paling sempit }\end{array}$ \\
\hline $\begin{array}{l}\text { Bersikap dan } \\
\text { berprilaku jujur }\end{array}$ & Lebar hidung & $\begin{array}{l}\text { Lebar hidung } \\
\text { paling kecil }\end{array}$ & $\begin{array}{l}\text { Lebar hidung } \\
\text { sedang }\end{array}$ & $\begin{array}{l}\text { Lebar hidung } \\
\text { paling lebar }\end{array}$ \\
\hline $\begin{array}{l}\text { Cara } \\
\text { penyampaian } \\
\text { materi sistematis }\end{array}$ & Panjang alis & $\begin{array}{l}\text { Panjang alis } \\
\text { paling panjang }\end{array}$ & $\begin{array}{l}\text { Panjang alis } \\
\text { sedang }\end{array}$ & $\begin{array}{l}\text { Panjang alis } \\
\text { paling pendek }\end{array}$ \\
\hline $\begin{array}{l}\text { Teknik } \\
\text { penyampaian } \\
\text { materi menarik }\end{array}$ & Kelengkungan alis & $\begin{array}{l}\text { Alis agak } \\
\text { miring keatas }\end{array}$ & Alis mendatar & $\begin{array}{l}\text { Alis miring } \\
\text { kebawah }\end{array}$ \\
\hline $\begin{array}{l}\text { Bersikap } \\
\text { komunkatif }\end{array}$ & Panjang mulut & $\begin{array}{l}\text { Mulut paling } \\
\text { panjang }\end{array}$ & Mulut sedang & Mulut sedang \\
\hline $\begin{array}{l}\text { Berpenampilan } \\
\text { Rapi dan sopan }\end{array}$ & Kelengkungan mulut & $\begin{array}{l}\text { Mulut } \\
\text { melengkung } \\
\text { keatas }\end{array}$ & $\begin{array}{l}\text { Mulut } \\
\text { mendatar }\end{array}$ & $\begin{array}{l}\text { Mulut } \\
\text { mendatar }\end{array}$ \\
\hline
\end{tabular}

Dari Tabel 2 Berdasarkan hasil survei penilaian karakteristik dosen dari 98 mahasiswa jurusan Matematika FMIPA UNTAN diambil modus dari setiap variabel, hasil dari karakteristik ke-13 dosen jurusan Matematika FMIPA UNTAN disajikan dalan Tabel 3 berikut : 
Tabel 3 Hasil penilaian mahasiswa terhadap ke- 13 dosen

\begin{tabular}{|c|c|c|c|c|c|c|c|c|c|c|c|c|c|c|}
\hline \multirow{2}{*}{ Variabel } & \multirow{2}{*}{ Kategori } & \multicolumn{13}{|c|}{ Dosen } \\
\hline & & $\mathrm{A}$ & B & $\mathrm{C}$ & D & $\mathbf{E}$ & $\mathbf{F}$ & $\mathbf{G}$ & $\mathbf{H}$ & I & $\mathbf{J}$ & $\mathbf{K}$ & $\mathrm{L}$ & M \\
\hline \multirow{3}{*}{ Keramahan terhadap mahasiswa } & Kurang & 1 & - & 2 & 5 & 3 & 2 & 3 & 1 & 7 & - & - & - & 8 \\
\hline & Sedang & 21 & 4 & 22 & 33 & 23 & 22 & 30 & 25 & 57 & 6 & 93 & 14 & 44 \\
\hline & Baik & 76 & 94 & 74 & 60 & 72 & 74 & 65 & 72 & 34 & 92 & 5 & 84 & 46 \\
\hline \multirow{3}{*}{ Memiliki wawasan yang luas } & Kurang & - & - & 1 & - & 1 & 2 & - & 1 & 1 & - & 1 & 1 & 0 \\
\hline & Sedang & 2 & 10 & 19 & 16 & 18 & 42 & 3 & 15 & 7 & 21 & 19 & 28 & 16 \\
\hline & Baik & 96 & 88 & 78 & 82 & 79 & 54 & 95 & 82 & 90 & 77 & 78 & 69 & 82 \\
\hline \multirow{3}{*}{ Kreatif,dinamis dan inovatif } & Kurang & 5 & 5 & 5 & 2 & 2 & 5 & 1 & 3 & 2 & 3 & 2 & 1 & 2 \\
\hline & Sedang & 24 & 34 & 32 & 36 & 38 & 47 & 20 & 25 & 28 & 33 & 27 & 38 & 29 \\
\hline & Baik & 69 & 59 & 61 & 60 & 58 & 46 & 77 & 70 & 68 & 62 & 69 & 59 & 67 \\
\hline \multirow{3}{*}{ Bijak dalam menghadapi masalah } & Kurang & - & 1 & 1 & 1 & 2 & 1 & 1 & 1 & 7 & - & - & 2 & 1 \\
\hline & Sedang & 15 & 21 & 35 & 16 & 28 & 38 & 11 & 24 & 38 & 19 & 20 & 30 & 27 \\
\hline & Baik & 83 & 76 & 62 & 81 & 68 & 59 & 86 & 73 & 53 & 79 & 78 & 66 & 70 \\
\hline \multirow{3}{*}{ Bersikap dan berprilaku jujur } & Kurang & - & - & - & - & - & - & 1 & 0 & 1 & - & - & - & - \\
\hline & Sedang & 2 & 2 & 6 & 2 & 7 & 7 & 4 & 11 & 11 & 3 & 3 & 9 & 8 \\
\hline & Baik & 96 & 96 & 92 & 96 & 91 & 91 & 93 & 87 & 86 & 95 & 94 & 89 & 90 \\
\hline \multirow{3}{*}{ Cara penyampaian materi sistematis } & Kurang & 9 & 10 & 3 & 2 & 2 & 2 & 1 & 2 & 1 & 1 & 1 & 1 & 2 \\
\hline & Sedang & 35 & 33 & 33 & 26 & 22 & 37 & 26 & 17 & 31 & 20 & 20 & 38 & 25 \\
\hline & Baik & 54 & 55 & 62 & 70 & 74 & 59 & 71 & 79 & 66 & 77 & 77 & 59 & 71 \\
\hline \multirow{3}{*}{ Teknik penyampaian materi menarik } & Kurang & 9 & 14 & 8 & 5 & 5 & 5 & 4 & 2 & 4 & 2 & 1 & 5 & 3 \\
\hline & Sedang & 36 & 49 & 53 & 37 & 29 & 52 & 36 & 35 & 46 & 36 & 31 & 45 & 46 \\
\hline & Baik & 53 & 35 & 37 & 56 & 64 & 41 & 58 & 61 & 48 & 60 & 67 & 48 & 49 \\
\hline \multirow{3}{*}{ Bersikap komunikatif } & Kurang & 4 & 5 & 5 & 3 & 2 & 4 & 2 & 1 & 2 & - & 1 & 2 & 1 \\
\hline & Sedang & 19 & 24 & 24 & 16 & 14 & 21 & 22 & 21 & 34 & 14 & 13 & 18 & 26 \\
\hline & Baik & 75 & 69 & 69 & 79 & 82 & 73 & 74 & 76 & 62 & 84 & 84 & 78 & 71 \\
\hline \multirow{3}{*}{ Berpenampilan rapi dan sopan } & Kurang & - & - & - & - & - & - & - & 1 & - & - & - & - & 1 \\
\hline & Sedang & 1 & 2 & 2 & 2 & 3 & 4 & 4 & 2 & 2 & 3 & 2 & 3 & 4 \\
\hline & Baik & 97 & 96 & 96 & 96 & 95 & 94 & 94 & 95 & 96 & 95 & 96 & 95 & 93 \\
\hline
\end{tabular}

Warna hitam tebal pada Tabel 3 adalah nilai modus penilaian mahasiswa. Dari Tabel 3 dapat dilihat bahwa sebanyak 76 mahasiswa menilai keramahan dosen A terhadap mahasiswa dengan kategori baik, dan 57 mahasiswa menilai keramahan dosen I terhadap mahasiswa dengan kategori sedang dengan kata lain mahasiswa menilai keramahan dosen A, B, C, D, E, F, G, H, J, L, dan M terhadap mahasiswa dengan kategori baik dan untuk keramahan dosen I dan $\mathrm{K}$ terhadap mahasiswa dengan kategori sedang, penilaian untuk variabel lain dapat dilihat pada Tabel 3. Ditinjau dari hasil penilaian mahasiswa terhadap kinerja dosen pada Tabel 3, diperoleh nilai pengukuran variabel masing-masing dosen pada Tabel 4 berikut: 
Tabel 4 Nilai pengukuran masing-masing dosen

\begin{tabular}{|c|c|c|c|c|c|c|c|c|c|c|c|c|c|c|}
\hline \multirow{2}{*}{ Variabel } & \multirow{2}{*}{ Parameter } & \multicolumn{13}{|c|}{ Dosen } \\
\hline & & $\mathbf{A}$ & B & $\mathbf{C}$ & D & $\mathbf{E}$ & $\mathbf{F}$ & $\mathbf{G}$ & $\mathbf{H}$ & I & $\mathbf{J}$ & $\mathbf{K}$ & $\mathbf{L}$ & $\mathbf{M}$ \\
\hline \multirow{3}{*}{$\begin{array}{c}\text { Keramahan terhadap } \\
\text { mahasiswa }\end{array}$} & Panjang mata & 1 & 1 & 1 & 1 & 1 & 1 & 1 & 1 & 0,6 & 1 & 0,6 & 1 & 1 \\
\hline & Lebar mata & 0,6 & 0,6 & 0,6 & 0,6 & 0,6 & 0,6 & 0,6 & 0,6 & 0,4 & 0,6 & 0,4 & 0,6 & 0,6 \\
\hline & Jarak kedua mata & 0,8 & 0,8 & 0,8 & 0,8 & 0,8 & 0,8 & 0,8 & 0,8 & 0,55 & 0,8 & 0,55 & 0,8 & 0,8 \\
\hline $\begin{array}{c}\text { Memiliki wawasan yang } \\
\text { luas }\end{array}$ & Panjang wajah & 1 & 1 & 1 & 1 & 1 & 1 & 1 & 1 & 1 & 1 & 1 & 1 & 1 \\
\hline $\begin{array}{c}\text { Kreatif,dinamis dan } \\
\text { inovatif }\end{array}$ & Lebar wajah & 0,4 & 0,4 & 0,4 & 0,4 & 0,4 & $\begin{array}{c}0,27 \\
5 \\
\end{array}$ & 0,4 & 0,4 & 0,4 & 0,4 & 0,4 & 0,4 & 0,4 \\
\hline $\begin{array}{c}\text { Bijak dalam menghadapi } \\
\text { masalah }\end{array}$ & Panjang hidung & 0,7 & 0,7 & 0,7 & 0,7 & 0,7 & 0,7 & 0,7 & 0,7 & 0,7 & 0,7 & 0,7 & 0,7 & 0,7 \\
\hline $\begin{array}{l}\text { Bersikap dan berprilaku } \\
\text { jujur }\end{array}$ & Lebar hidung & 0,2 & 0,2 & 0,2 & 0,2 & 0,2 & 0,2 & 0,2 & 0,2 & 0,2 & 0,2 & 0,2 & 0,2 & 0,2 \\
\hline $\begin{array}{c}\text { Cara penyampaian materi } \\
\text { sistematis } \\
\end{array}$ & Panjang alis & 1 & 1 & 1 & 1 & 1 & 1 & 1 & 1 & 1 & 1 & 1 & 1 & 1 \\
\hline $\begin{array}{c}\text { Teknik penyampaian } \\
\text { materi menarik }\end{array}$ & Kelengkungan alis & 1 & 0,5 & 0,5 & 1 & 1 & 0,5 & 1 & 1 & 1 & 1 & 1 & 1 & 1 \\
\hline Bersikap komunikatif & Panjang mulut & 1 & 1 & 1 & 1 & 1 & 1 & 1 & 1 & 1 & 1 & 1 & 1 & 1 \\
\hline $\begin{array}{l}\text { Berpenampilan rapi dan } \\
\text { sopan }\end{array}$ & $\begin{array}{l}\text { Kelengkungan } \\
\text { mulut }\end{array}$ & 4 & 4 & 4 & 4 & 4 & 4 & 4 & 4 & 4 & 4 & 4 & 4 & 4 \\
\hline
\end{tabular}

Berdasarkan nilai pengukuran variabel masing-masing dosen pada Tabel 4 diperoleh empat kelompok Chernoff Faces dari 13 dosen jurusan Matematika FMIPA UNTAN sebagai berikut:

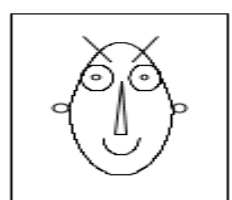

(a)

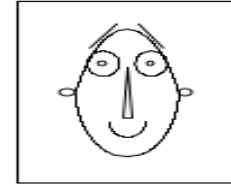

(b)

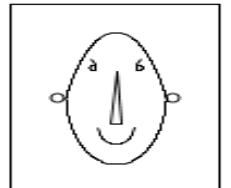

(c)

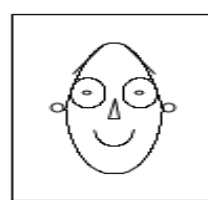

(d)

Gambar 2 pengelompokkan wajah kartun Chernoff ke-13 dosen

Pada Gambar 2(a) diperoleh wajah kartun Chernoff untuk dosen A, D, E, G, H, J, L, dan M, sedangkan untuk Gambar 2(b) diperoleh wajah kartun Chernoff untuk dosen B dan C, dan Gambar 2(c) diperoleh wajah kartun Chernoff untuk dosen I dan K, serta Gambar 2(d) diperoleh wajah kartun Chernoff untuk dosen F.

\section{KINERJA DOSEN KESELURUHAN}

Selanjutnya dari Tabel 4 diperoleh nilai modus masing-masing variabel yang digunakan untuk menggambar wajah Chernoff dosen keseluruhan ,adapun nilai pengukuran modus dapat dillihat pada Tabel 5 berikut : 
Tabel 5 Nilai pengukuran modus masing-masing variabel

\begin{tabular}{|c|c|c|}
\hline Variabel & Parameter & $\begin{array}{l}\text { Pengukuran } \\
\text { sketsa }\end{array}$ \\
\hline \multirow{3}{*}{$\begin{array}{l}\text { Keramahan terhadap } \\
\text { mahasiswa }\end{array}$} & Panjang mata & 1 \\
\hline & Lebar mata & 0,6 \\
\hline & Jarak kedua mata & 0,8 \\
\hline $\begin{array}{l}\text { Memiliki wawasan } \\
\text { yang luas }\end{array}$ & Panjang wajah & 1 \\
\hline $\begin{array}{l}\text { Kreatif,dinamis,dan } \\
\text { inovatif }\end{array}$ & Panjang hidung & 0,4 \\
\hline $\begin{array}{l}\text { Bijak dalam } \\
\text { menghadapi masalah }\end{array}$ & Lebar wajah & 0,7 \\
\hline $\begin{array}{l}\text { Bersikap dan } \\
\text { berprilaku jujur }\end{array}$ & Lebar hidung & 0,2 \\
\hline $\begin{array}{l}\text { Cara penyampaian } \\
\text { materi sistematis }\end{array}$ & Panjang alis & 1 \\
\hline $\begin{array}{l}\text { Teknik penyampaian } \\
\text { materi menarik }\end{array}$ & Kelengkungan alis & 1 \\
\hline Bersikap komunikatif & Panjang mulut & 1 \\
\hline $\begin{array}{l}\text { Berpenampilan rapi } \\
\text { dan sopan }\end{array}$ & $\begin{array}{l}\text { Kelengkungan } \\
\text { mulut }\end{array}$ & 4 \\
\hline
\end{tabular}

Dari nilai pengukuran wajah pada Tabel 5 diperoleh wajah Chernoff dosen keseluruhan sebagai berikut:

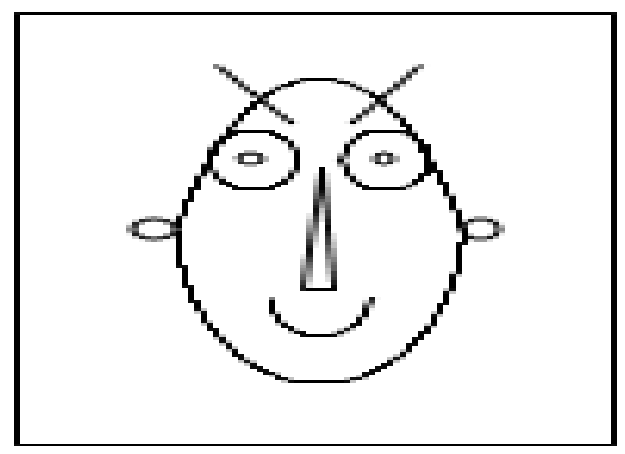

\section{Gambar 3 Sketsa wajah kartun Chernoff dosen keseluruhan}

Wajah Chernoff dosen keselurahan mempunyai mata paling panjang, lebar mata paling lebar dan jarak antar mata dekat menunjukkan keramahan terhadap mahasiswa baik, panjang wajah paling panjang menunjukkan bahwa memiliki wawasan luas yang baik, wajah yang paling lebar menunjukkan kreatif,dinamis,dan inovatif yang baik, hidung paling panjang menunjukkan bijak dalam menghadapi masalah dengan baik, lebar hidung paling kecil menunjukkan bersikap dan berprilaku jujur dengan baik, panjang alis yang paling panjang menunjukkan cara penyampaian materi sistematis sudah baik, alis agak miring keatas menunjukkan teknik penyampaian materi menarik sudah baik, kemudian, mulut yang paling panjang menunjukkan bersikap komunikatif yang baik, dan mulut melengkung keatas menunjukkan berpenampilan rapi dan sopan dengan baik. Terlihat dari Gambar 3 bahwa semua variabel bernilai baik sehingga kinerja keseluruhan dosen jurusan 
Matematika FMIPA UNTAN sudah baik.

\section{PENUTUP}

Berdasarkan pembahasan yang telah dipaparkan, maka dapat ditarik kesimpulan bahwa kinerja dosen jurusan Matematika FMIPA UNTAN secara keseluruhan sudah baik dalam bidang pengajaran menggunakan metode Chernoff Faces. Variabel-variabel yang menyatakan kinerja dosen Jurusan Matematika FMIPA UNTAN sudah baik adalah :

1. Keramahan terhadap mahasiswa

2. Memiliki wawasan yang luas

3. Kreatif,dinamis dan inovatif

4. Bijak alam menghadapi masalah

5. Bersikap dan berprilaku jujur

6. Cara penyampaian materi sistematis

7. Teknik penyampaian materi menarik

8. Bersikap komunikatif

9. Berpenampilan rapi dan sopan

\section{DAFTAR PUSTAKA}

[1] Johnson, R.A. dan Wichern, D.W. Applied Multivariat Statistical Analysis. Pearson Education: Inc. United States of America; 2007.

[2] Putri, G.A.M.A., Kencana, I.P.E.N., dan Sukarsa, K.G. Analisis Kinerja Dosen Jurusan Matematika FMIPA UNUD dengan Metode Chernoff Faces. E-Jurnal Matematika. 2012; (1):32-39.

[3] Kusnandar, D., Debataraja, N.N., Mara, M.N., dan Satyahadewi, N. Metode Statistika Serta Aplikasinya dengan MINITAB, Excel dan SPSS. UNTAN Press: Pontianak; 2019.

[4] Kusnandar,N., Sumantri, B., dan Indahwati, Kajian terhadap Karakteristik Tampilan Chernoff Faces sebagai Alat Eksplorasi Data secara Visual. 2002; 2-8.

ROHANI

SHANTIKA MARTHA

NURFITRI IMRO’AH
: Jurusan Matematika FMIPA UNTAN, Pontianak rohanioni31@gmail.com

: Jurusan Matematika FMIPA UNTAN, Pontianak shantika.martha@math.untan.ac.id

: Jurusan Matematika FMIPA UNTAN, Pontianak

nurfitriimroah@math.untan.ac.id 